\title{
KONDITSIONAALI OMANDAMISEST EESTI LAPSEKEELES
}

Renate Pajusalu, Pirko Tõugu, Maigi Vija, Tiia Tulviste

Ülevaade. Artiklis käsitletakse verbi konditsionaalivormide arengut eesti lapsekeeles. Kasutatakse kahte korpust: Andrease CHILDES-i korpust, milles leidub ühe lapse salvestisi vanusest 1;7 kuni 3;1, ja 3-5-aastaste laste mängude salvestisi. Esimesed preesensi konditsionaali vormid ilmuvad Andrease keelde 2 aasta vanuses, regulaarseks ja sagedaseks saab neid aga pidada umbes vanuses 2;6. Laps kasutab neid kõige rohkem et-konstruktsioonides, ema aga lapsele suunatud kõnes kõige rohkem modaalverbikonstruktsioonides. Mänguvestluste põhjal võib öelda, et konditsionaali preesens esineb juba kõigis täiskasvanupärastes funktsioonides (s.t nii kujuteldava olukorra tähenduses kui viisakusvahendina), kuid perfektivormid on veel selleski vanuses piiratud väheste kasutuskontekstidega.*

Võtmesõnad: esimese keele omandamine, verbimorfoloogia, konditsionaal, konstruktsioonid, eesti keel

\section{Konditsionaal eesti keeles ja tingimuslik järeldamine}

Konditsionaal ehk tingiv kõneviis moodustatakse eesti keeles tunnuse $-k s$ abil, millele võib 1. ja 2. isiku puhul liituda pöördelõpp (sel juhul on tunnus enne pöördelõppu kujul -ksi-). Konditsionaalil on kaks ajavormi: preesens ja perfekt, viimase puhul liitub tunnus $-k s(i)$ - abiverbile olema. Konditsionaali põhitähenduseks eesti keeles on märkida sündmuste mittereaalsust vaatlushetkel (EKG II: 34-35).

Helle Metslang (1999) on leidnud, et eesti konditsionaalil on kaks põhitähendust. Ühelt poolt võib konditsionaalivormis verb osutada sellele, et kõne all olev sündmus ei ole tegelikult toimunud, kuid teatud tingimustel võib või võis toimuda. Lause oleks ma vaid kohal olnud! tähendab muuhulgas seda, et

* Uurimust on toetanud Eesti Teadusfondi grant 7492 ning Haridus- ja Teadusministeeriumi sihtfinantseeritavad 
kõneleja ei olnud kohal. Võrreldes eitava lausega (ma ei olnud kohal) lisandub mittereaalsuse tähendusele mentaalse ruumi konstruktsioon, milles see sündmus toimunuks. Kõneleja on ilmselt tahtnud öelda, et kui ta oleks olnud, oleks ka asjad teisiti (paremini) läinud. Sellist tinglike olukordade konstrueerimist on nimetatud tingimuslikuks ehk konditsionaalseks järeldamiseks (ingl conditional reasoning) ja inglise keeles eelkõige käsitletud tingimuslausete (conditionals või if-clauses) tähendusega seoses (Dancygier, Sweetser 2005: $5 \mathrm{jm}$ ).

Teiselt poolt on eesti konditsionaalil suhtluses täita ka hoopiski erinevad, suhtluse reguleerimisega seotud rollid. Sündmuse mittereaalsuse asemel võib konditsionaal väljendada ka viisakusest või tagasihoidlikkusest tingitud umbmäärastamist, eriti kui konditsionaalivormis on modaalverb (peaks, võiks, saaks jm, vt ka R. Pajusalu, K. Pajusalu 2004). Kui öeldakse peaks minema hakkama, ei mõelda ainult seda, et veel ei ole hakatud (seda väljendaks ka peab minema hakkama), vaid et kõneleja ei taha ühel või teisel põhjusel (näiteks viisakuse tõttu) olla liiga kategooriline. Sellistel juhtudel on konditsionaalil kanda kõneakti vormistav roll, sest konditsionaal näitab, et tegemist on just palve või ettepanekuga. Võime neid nimetada ka viisakuskonditsionaalideks.

Konditsionaali kahte põhifunktsiooni on nimetatud ka raami- ja intentsionaalseks tõlgenduseks (Metslang 1999, Kauppinen 1998), esimene tähistab seda olukorda, kus konditsionaal väljendab sündmuse toimumist ainult mentaalses "raamis", mitte tegelikus ruumis; teine kõiki neid juhtumeid, kus konditsionaali ülesandeks on vormistada lausungi intentsiooni, s.t interpersonaalseid või modaalseid tähendusvarjundeid (viisakus, ebakindlus, ettepanek käsu asemel jms). Interpretatsioonid võivad ka omavahel põimuda ja sõltuda väga suures osas kontekstist (näiteks konditsionaalse relatiivlause kontekstilisest interpretatsioonist, vt R. Pajusalu, K. Pajusalu 2010).

\section{Grammatika tekkest ja konditsionaalist}

Artikkel käsitleb verbi konditsionaalivormide omandamist lapsekeeles. Põhiline siinkohal tõstatuv üldteoreetiline küsimus on see, kas lapsed peaksid konditsionaalivormide omandamiseks suutma ka tingimuslikult järeldada või omandatakse konditsionaalsed vormid eelkõige niisuguste konstruktsioonide kaudu, mis on seotud konkreetsete olukordadega ja milles konditsionaalivormid esinevad pigem intentsionaalses interpretatsioonis ehk toimivad kõneakti suhtluslike parameetrite vormistamisel. Viimasel juhul pole konditsionaalivormide kasutamiseks mentaalse ruumi mittereaalsete komponentide kujutlemist esialgu tarviski. Teiselt poolt peaks laps intentsionaalse tõlgendusega vormide jaoks (peaks, võiks, tahaks) mingilgi määral tajuma viisakuskoodi ja sellest tulenevat umbmäärastamist. Seega on nii raamitõlgenduse kui intentsionaalse tõlgenduse korral täielikuks täiskasvanupäraseks omandamiseks vaja mitte ainult morfoloogia ja konstruktsioonide, vaid ka üsna abstraktsete kategooriate (tingimuslik mõtlemine, viisakus) omandamist.

Kasutuspõhises keele omandamise mudelis (nt Tomasello 2005: 5) on võetud omaks seisukoht, et keele olemus on sümbolites, s.t tähenduslikes üksustes ja konstruktsioonides. Grammatika kui abstraktne süsteem on alles sekundaarne ja areneb lapsel eelkõige sisendkeelest omandatud konstruktsioonide kaudu. Konst- 
ruktsioonide all mõeldakse vormi ja tähenduse vastavusi, milles on n-ö lünki, mida võib täita erinevate üksustega (konstruktsioonide kohta lapse keelelises arengus vt nt Clark, Kelly 2006). Mitmed uurimused näitavad ka, et grammatika areneb tihedas seoses sõnavaraga, s.t mitte eraldi süsteemina, vaid üksikute sõnavormide ja konstruktsioonidena (nt soome keele kohta Stolt jt 2009). Teiselt poolt tuleb ka tähele panna, et konditsionaal on lapse jaoks suhteliselt regulaarne aglutinatiivne verbivorm: see moodustatakse preesensi tüvest, mis on lapsel tüüpiliselt esimene kasutusele tulev verbitüvi (kas siis preesensi või imperatiivi tähenduses, verbi aegade omandamise kohta vt Argus 2006) ja millele liidetakse tunnus $k s(i)^{1}$. Kuigi oletame, et esimesed konditsionaalivormid omandatakse tervikuna, ei ole ka nende sisemine struktuur keerukas ja morfoloogilisest vaatenurgast peaks see olema omandatav suhteliselt varakult.

Sisendkeelt oluliseks pidades oletame, et kõigepealt tekivad lapse kõnesse need väljendid, mida ta sageli on kuulnud, ja alles hiljem need, mida ta loovalt ise moodustab (vt nt Clark, Kelly 2006). Samas ei pruugi ainult sagedane esinemine sisendis olla ainsaks omandamise põhjuseks: laps valib ikkagi need keelelised vahendid, mida ta suhtluseks vajab (Kauppinen 1998). Lapse keeleline sisend on eelkõige argivestlus, kirjakeele keerulised konstruktsioonid teda esialgu ei mõjuta. Tartu ülikooli suulise kõne korpuse ${ }^{2}$ argivestluste põhjal võib öelda, et konditsionaali kasutatakse eesti argikõnes tüüpiliselt järgmistes tähendustes ja kontekstides (vt täpsemalt R. Pajusalu, K. Pajusalu 2004, 2010, R. Pajusalu, ilmumas).

A. Modaalverbide konditsionaalivormid preesensis, mis esinevad enamasti ilma isikutunnuse ja pronoomenita, kuid sisaldavad oletuslikult kõnelejat ühe (potentsiaalse) tegijana. Sõltuvalt kontekstist võivad nad olla n-ö sisekõnelised (kõneleja arutleb kõva häälega, mida peaks tegema või võiks teha) või laias tähenduses ettepanekud (kõneleja arutleb tulevase käitumise strateegiate üle):

peaks - ettepanekute ja palvete väljendusena, nt peaks helistama tädi Juulile;

võiks - eelkõige ettepanekutes, nt kalapulki võiks teha;

tahaks - eelkõige kõneleja enda soovide väljendusena, nt tahaks tegelikult mingit raviteed aga noh.

B. Perfektivormis kahetsused (se oleks ikka stiilne maja olnd) või narratiivides kirjeldused sündmustest, mis peaaegu oleksid juhtunud, kuid ei juhtunud siiski (nn avertiiv ${ }^{3}$, nt $m a=$ oleks $=$ muidu (.) hooga nagu vastu aknalauda või kuskile maandunud).

C. Et-kõrvallaused eesmärgi väljendajana või mõtlemisverbide laiendajana (et papi nagu hakkaks mõtlema tal=on potensiaalne ostja olemas), mille puhul kõrvallausega kirjeldatu ei ole tegelikult toimunud, sest on alles mingi teise (suhtlus)tegevuse eesmärk.

Täiskasvanute argikõne sagedaste konstruktsioonide hulgas ei ole neid, mis seostuksid eesti keele tingiva kõneviisiga kui tingimuse esitajaga (tuleksin, kui

\footnotetext{
ks on eesti morfoloogias küllaltki "koormatud" häälikujärjend: see esineb ka noomenite translatiivis ja verbide impersonaalivormides. Kuidas need tähendused välja kujunevad, on tulevase uurimistöö ülesanne.

2 http://www.cl.ut.ee/suuline/ (20.02.11), sellest korpusest pärinevad ka siinse osa näited.

3 Eesti keele avertiivi on käsitlenud Mati Erelt ja Helle Metslang (2009). Nad leiavad, et eesti keele perfekti kondit-

sionaal vajab avertiivseks tõlgenduseks mõnda adverbi, nt peaaegu või äärepealt (op.cit. 185-186). Lapsekeeles ja ka

täiskasvanu suulises kõnes näib üks tüüpilisi adverbiaale selles kontekstis olevat muidu.
} 
jõuaksin). Rühma A kuuluvad eelkõige intentsionaalse interpretatsiooni juhtumid ehk viisakuskonditsionaalid, kus konditsionaalne vorm ei kanna irreaalsuse tähendust, vaid on pelgalt viisakuse teenistuses. Rühmad B ja C on aga tingimusliku mõtlemise väljenduseks, sest neil juhtudel oleks miski võinud toimuda (B) või toimub kavatsuste täitumise korral (C). Kui oletada, et lapse keeleline areng sõltub eelkõige sisendkeelest, siis peaksid tema kõnesse esimestena tulema A-tüüpi intentsionaalse tõlgendusega modaalverbide konditsionaalivormid, aga ka B- ja C-rühma konstruktsioonid.

Ühe soome lapse konditsionaali omandamist uurinud Anneli Kauppinen (1998) on näidanud, et konditsionaal tuleb lapse kõnesse konstruktsioonidena, eelkõige korduste kaudu. Sealjuures väljendavad esimesed konstruktsioonid kahe aasta vanuses (mitä täällä olisi 'mis siin oleks?') nii soovi kui fantaasiat ja alles hiljem hargnevad need kaks tähendust eri suhtluseesmärkideks. Kauppinen rõhutab, et lapse keeleline areng toimub muidugi vastavalt sisendkeeles olemasolevale, kuid laps korjab sellest välja eelkõige selle, mida ta oma suhtluseesmärkide täitmiseks vajab (Kauppinen 1998: 230). Soome konditsionaali kasutus on suuresti eesti keele omaga sarnane, kuid erineb siiski mõnes olulises aspektis, mistõttu selle omandamist saab eesti konditsionaali omandamisega küll võrrelda, kuid mitte tõmmata automaatseid paralleele. Suurim lapsekeeles oluliseks osutuv erinevus eesti ja soome konditsionaali vahel on soome konditsionaali rohke kasutus nn mänguplaneerimises, kus eesti lapsed kasutavad tavaliselt indikatiivi preesensit koos adverbiga mängult (sinä olisit prinsessa 'sina oled mängult printsess'; nyt ne hyppäis 'nüüd nad mängult hüppavad', vt Metslang 1999).

Inglise keele omandamise uurijad on olnud huvitatud verbi konditsionaalivormist eelkõige taotluse (palve/ettepanek, ingl request) kõneakti uurides. Kaudsetest nõudmistest (nt konditsionaali vormis) arusaamise üle otsustatakse selle põhjal, kas laps ema palve täidab või ei. Selliste uurimustega on leitud, et 2-4-aastane laps saab aru nii otsesest (nt imperatiivi vormis) kui kaudsest nõudmisest, kuigi otsestest nõudmistest saadakse paremini aru (Shatz 1978, Elrod 1987). Inglise keele omandamise vaatenurgast on uuritud ka tingimuslausete (if-lausete, ingl conditionals) omandamist. On väidetud, et lapsed hakkavad tingimuslauseid produtseerima kahe ja poole aasta vanuses, kuid omandavad süsteemi täielikult alles 8-aastaselt (Reilly 1986: 311). Nii hilise omandamise põhjuste üle on arutlenud nt Melissa Bowerman (1986), kes püstitab küll hüpoteesi tingimuslausete kognitiivsest ja/ või pragmaatilisest keerukusest, kuid jõuab siiski järeldusele, et kumbki ei tohiks takistada tingimuslausete varasemat tulekut keelde.

Varasemates lapsekeele uurimustes on analüüsitud peamiselt ema-lapse suhtlust. Samas on alates Jean Piaget' 1920.-30. aastate uurimustest arvatud, et laps kasutab keerukamaid keelekonstruktsioone just eakaaslastega suheldes: teised lapsed ei oska nii hästi kui täiskasvanud oletada, mida laps öelda tahab, ning seetõttu peab laps oma mõtteid selgemalt väljendama (Piaget 1932, Blum-Kulka, Snow 2004). Samuti on ema-lapse suhtluse korral võimalik, et laps imiteerib ema poolt öeldut, kuigi ise sama keelevormi veel ei kasuta; analüüsides lapse suhtlust oma eakaaslastega, on aga paremini näha, milliseid keelekonstruktsioone selles vanuses lapsed ise kasutavad. Käesoleva artikli materjal $3-5$-aastaste laste puhul ongi pärit suhtlusest eakaaslasega. 


\section{Materjal}

Siinne uurimus põhineb kahel korpusel. Andrease korpus (CHILDES-i eesti keele korpuse allkorpus ${ }^{4}$, koostanud Maigi Vija) sisaldab spontaanse kõne lindistusi vanusest 1;7.24-3;1.13, kokku umbes 74 tundi. Materjal on üles võetud Andrease kodus pooleteise aasta jooksul (iga kord 60 minutit) ning põhilised tegevused ema ja/või isa ning lapse vahelises vestluses on mängimine, raamatute vaatamine, söömine ja teised kodused askeldused. Tekstide transkribeerimiseks ja konditsionaalivormide otsimiseks on kasutatud programmi CLAN5 5

Teine korpus - mängukorpus - koosneb 16 videosalvestusest, kus lapsed mängivad kolmestes gruppides. Salvestised on tehtud Tartu kahe lasteaia kahes rühmas ajavahemikus 2007-2008 jätku-uuringuna Pirko Tõugu ja Tiia Tulviste (2010) artiklile, mis keskendus sotsiaalsete normide väljendamise ja keeleliste näitajate seoste uurimisele 3-7-aastaste laste kõnes.

Salvestusprotseduur oli mängukorpuse puhul järgmine. Esmalt käisid uurijad lasteaiarühmas vaba mängu ajal lastega tutvumas. Videosalvestise tegemisel selgitati lastele, et uurijad tahavad filmida seda, kuidas nad omavahel mängivad, ning paluti osalejatel leida endale kaks sõpra, kellega koos mängida. Samuti selgitati, et uurijad (täiskasvanud) on küll samas ruumis, kuid tööga hõivatud ega saa nendega hetkel koos mängida. Lastele kinnitati raadiosaatja ja nende mängu salvestatica 20 minuti vältel. Lapsed mängisid kolmeses grupis vabalt valitud mängu. Ülejäänud lapsed viibisid samal ajal õues või kõrvalruumis organiseeritud tegevusel. Lapsed ja nende vanemad olid teadlikud uurimuses osalemisest ning tegid seda vabatahtlikult. Lastel oli võimalik millal tahes uurimuses osalemisest keelduda. Salvestamiseks kasutati Käitumis- ja Terviseteaduste Tippkeskusele kuuluvat videoaparatuuri. Edasiseks analüüsiks salvestis transkribeeriti. Kokku osales 43 last vanuses 3;2-5;2 (keskmine vanus 4;1, standardhälve 5,8k), neist 18 poissi vanuses 3;2-4;9 (keskmine 4;1, standardhälve 5,2k) ja 25 tüdrukut vanuses 3;2-5;2 (keskmine vanus 4;1, standardhälve 6,3k). Viis last osales kahe grupi mängus. Laste nimed on näidetes esitatud kolmetäheliste varjunimedena.

Kaks kasutatud korpust erinevad teineteisest olulisel määral. Andrease korpuses vestleb laps oma vanematega, mängukorpuses vestlevad lapsed omavahel; Andreas vestleb vanematega erinevatel teemadel, mängukorpuses tegeldakse eelkõige mänguolukorraga ja selle planeerimisega. Andrease korpuse esimesed konditsionaalivormid on harvad, mistõttu järeldusi kasutuse algusetapi kohta tuleb teha väheste näidete põhjal. Kuigi nende kahe korpuse põhjal võib välja tuua üldiseid tendentse konditsionaali omandamises, jääb detailsem uurimus konditsionaalsete verbivormide omandamise algetapist ja seotusest vestluse tüübiga tulevikuülesandeks.

http://childes.psy.cmu.edu/data/Other/Estonian/ (20.02.2011). 


\section{Konditsionaali tulek keelde: esimesed kasutused Andrease korpuses}

Andrease ${ }^{6}$ korpuses leidus kokku 100 lapse ja 118 ema konditsionaalivormi (vt tabel 1). Andrease esimesed konditsionaalivormid on välviks 'värviks', ei oleks ja kasvaks (1)-(3), millest välviks (1) on registreeritud kohe kaheaastaseks saamise järel. Vanuses 2;0-2;1 tehtud salvestustes ongi ainult need kolm konditsionaali näidet, varasemas materjalis ei esine konditsionaali ei Andrease ega ema kõnes.

(1) Antsu 2;0.10. (Andreas hakkab mängima värvisegamise mängu, mida ta eelmisel päeval haiglas mängis, ning kommenteerib kõva häälega oma tegevust.)

${ }^{*}$ CHI: nii \# nüüd korki ka välviks [: värviks].

${ }^{*} \mathrm{CHI}$ : xx välviks [: värviks].

(2) Antsu 2;1.07.

${ }^{*} \mathrm{CHI}$ : <kuum ei oleks $>$ [+ I]. (EELNEVALT: ${ }^{*} \mathrm{FAT}:+$, et kuum ei oleks.)

${ }^{*} \mathrm{CHI}$ : <kuum ei oleks $>$ [+ SR $]$.

(3) Antsu 2;1.08.

${ }^{*}$ CHI: Antsu sõi vägasti [= väga hästi] otsa siin, nüüd kasvaks [= kasvab] suuleks [: suureks].

Pärast teist sünnipäeva on Andrease keeleline areng väga kiire, lindistustes leiduvad esimesed ainsuse adessiivi, ablatiivi, terminatiivi, translatiivi ja mitmete mitmuse käänete vormid ning miniparadigmad kasvavad paari nädala jooksul nelja- ja viieliikmelisteks (Argus 2004: 39-40). Samal ajal esimese konditsionaalivormiga ilmuvad ka esimesed impersonaalivormid, mille päris esimesed näited on kas mittetäielikud või analüüsimata üksustena omandatud vormid; täiskasvanupärane ladus impersonaalikasutus tuleb kohe pärast kolmandat sünnipäeva (Torn-Leesik, Vija, ilmumas). Seega on just teise sünnipäeva ajal Andrease arengus see etapp, kus ta eksperimenteerib verbivormidega.

Esimese konditsionaali moodi kasutuse välviks (1) põhjal ei saagi päris kindlalt öelda, kas tegemist ikka on konditsionaaliga või hoopis translatiiviga sõnast värv. See on ju periood, kus laps hakkab ise morfoloogilisi tunnuseid ja lóppe kombineerima verbide ja noomenitega. Tüvi värv ${ }^{7}$ esineb vanuses 2;0.-2;1 Andreasel nii nimisõnana (Antsu värv; Antsu pani värvi; kollast värvi ka; sinine värv üks; emme, aita värvi teha; sellega [*] värviga) kui ka verbi värvima vormidena (nagu issi värvib; ei saa värvida; issi värvinud). Selles vanuses meeldis Andreasele mängida värvisegamist ja seega on värv-tüvi tema leksikonis sagedane (40 esinemist lindistustes $2 ; 0 .-2 ; 1$ ), nii et on tõesti võimatu lõplikult otsustada, kas tegemist üldse on verbiga, kuigi see lausetervikut vaadates nii tundub.

Andrease materjali hulgas leidub veel üks huvitav näide, mis peegeldab seda, kuidas laps on sisendkeeles kuulnud, märganud ja meelde jätnud selle, et kasutatakse konditsionaali tunnust - $k s$, aga ta liidab selle valele sõnale, jättes modaalverbi peaks hoopis välja (seda vormi ei ole siinses uurimuses konditsionaaliks loetud):

6 Materjalis on kasutatud Andrease hellitusnime Antsu.

7 Keelepäevikus on seletatud, et värvima tähendab Andrease jaoks 'värvi segama' (mingi pulgataolise esemega). 
(4) (Andreas tsiteerib lasteluuletust "Muti metroo".)

2;0.7: *CHI: <mutt aina töötab varstiks saada> ["]. (= Mutt aina töötab ja varsti peaks saama...)

Järgmised kaks konditsionaalivormi kasutust ei oleks ja kasvaks (2), (3) on Andrease kõnest leitud kuu aega hiljem, vanuses 2;1. Nendes näidetes on kindlasti tegemist konditsionaalivormidega, kuid needki pole täielikult täiskasvanupärased. Näites (2) on laps vahetult korranud isa lausungit (vt vahetu korduse kohta Kauppinen 1998: 41 jj). Kuna laps ei korda kõike, mida kuuleb, vaid ainult seda, mida tal on oma suhtluseesmärkide täitmiseks vaja, ja kordused on osa igast omandamisprotsessist, käsitletakse siinkohal kordusi võrdväärsena täiesti produktiivsete vormidega. Näites (2) on isa eelnevalt kasutanud et- konstruktsiooni, mis väljendab soovi ja eesmärki. Andreas kordab seda lauset, kuid ilma sidesõnata et. Huvitav on see, et Anneli Kauppineni soome lapse materjalis on esimese produktiivse etkonstruktsioonina käsitletud täpselt sama sisuga lausung: ettei olek kuumaa 'et ei oleks kuum' (Kauppinen 1998: 51).

Andrease näidet kasvaks suuleks (3) võiks pidada ka üleüldistamise tõttu tekkinud ühildumisveaks, oletades, et laps lisab translatiivi käändelõpu ka verbile. Andreas on selleks ajaks jõudnud protomorfoloogilisse perioodi ${ }^{8}$ ja hakkab ise morfoloogilisi tunnuseid ja lõppe kombineerima verbide ja noomenitega, analüüsimata üksuste kõrval hakkab ta kasutama analoogiamoodustisi. Siiski on näite (3) interpreteerimine konditsionaalivormiks meie arvates piisavalt tõenäoline, sest arvatavasti on söömise kontekstis talle tihti öeldud, et laps peab palju sööma, et kasvaks suureks.

Täiskasvanu argikõne kasutustega võrreldes tundub esmahetkel üllatav see, et vanuses 2;0-2;1 leitud kolmest konditsionaalist kaks (värviks ja kasvaks) on sellised, mis on moodustatud tavalistest sisuverbidest (s.t mitte modaalverbidest), kuigi need verbivormid täiskasvanute argikõnes muidu eriti sagedased ei ole. Üheks põhjuseks võib siin olla ka modaalverbide üldine kognitiivne keerukus. ${ }^{9}$ Samas ei ole nende vormide kasutus täielikult täiskasvanupärane: näib, et laps on mõistnud, et konditsionaaliga saab väljendada midagi sellist, mida päriselt olemas ei ole, aga mida laps sooviks või on kuulnud täiskasvanuid soovivat (tahaks värvida, suureks kasvada, ära jahutada). Konditsionaali täiskasvanupärast kasutust ei ole Andreas 2 aasta vanuses veel omandanud.

Järgmises salvestusperioodis (vanus 2;6-2;8) esineb Andreasel kokku 5 konditsionaalivormi (näited 5-8). Näites (5) on registreeritud viimane mittetäiskasvanupärane vorm on vajaks, hiljem neid enam ei esine. ${ }^{10}$ Selle "omaloomingulise" moodustise taga on ilmselt see, et laps kombineerib omavahel valesti kahte erinevat, kuid väga sarnast konstruktsiooni on vaja ja oleks vaja ning neist moodustubki on vajaks. Samas olukorras hetk hiljem kasutab ta kohe ise ka õiget konstruktsiooni (5b). Neljast täiskasvanupärasest vormist kolm on argikeeleski väga sagedased konditsionaalivormid (oleks, peaks, võiks) ja esinevad Andreasel modaalkonstruktsioonides, väljendades veel toimumata soovitud tulemust. Ka üks sisuverb läheks (mida võib tegelikult ka käsitleda pooleldi grammatilise verbina) väljendab soovitud

\footnotetext{
8 Periodiseeringu kohta vt Dressler jt 2002.

9 Itaalia keele modaalverbide omandamise uurimisel on saadud tulemusi, mis näitavad, et modaalverbide konditsionaalsete ja indikatiivsete vormide eristamine algab alles 5-aastaselt ja kogu modaalsuse väli omandatakse ehk alles 12-aastaselt (Bascelli, Barbieri 2002). Eesti laste materjal näitab siiski, et täiskasvanupäraseid konditsionaalseid konstruktsioone toodab laps juba varem, kuid see muidugi ei tähenda, et ta mõistaks kõiki kasutusnüansse.

10 Anneli Kauppineni (1998: 84) soome materjalis on samuti näiteid sellest, kuidas laps lisab konditsionaali tunnuse mujale kui verbile, nt mitä Tjottaisi ottaa.
} 
tulevast seisundit, kuid erinevalt näidetest (5)-(7) esineb et-konstruktsioonis (8). Kõik neli on tuumverbid, mida laps üldiselt ka muidu suhteliselt vara omandab (vt Tragel 2003, Pajusalu jt 2004). Modaalverbide puhul oleks küll ilmselt liialdus öelda, et laps need juba esimeste kasutuste ajal on täielikult omandanud, kuid Andrease materjalis esinevad võima ja pidama juba vanuses 2;0-2;1.

(5) Andreas 2;6.12

a. *CHI: kõrvale, kõrvale on vajaks kommi.

b. ${ }^{*} \mathrm{CHI}$ : kõrvale oleks vaja kommi.

(6) Andreas 2;7.12

${ }^{*} \mathrm{CHI}$ : jah, nina võiks küll panna.

(7) Andreas 2;8.13

${ }^{*} \mathrm{CHI}$ : mina peaks bussi peale tooma asju.

(8) Andreas 2;8.13

${ }^{*}$ CHI: kõvasti, et läheks mina puhtaks.

Kolmeaastaselt on Andreasel juba palju erinevaid ja täiskasvanupäraseid konditsionaalivorme. Näited (9) -(11) on salvestatud kolmandal sünnipäeval ja on täiskasvanu argikõnet arvestades täiesti ootuspärased: (9) esitab vormi tahaks abil ettepaneku, (11) on et-konstruktsioon. Huvitav on näide (10), milles laps esitab selgelt tingimusliku alistusseosega lause o tähte oleks vaja siia, sïs oleks liblikas, mille puhul on vaja ka tingimusliku järeldamise oskust.

(9) Andreas 3;0.0

${ }^{*}$ CHI: kas sa tahaks seda süüa?

(10) Andreas 3;0.0

${ }^{*} \mathrm{CHI}$ : vaata, aga ma näitan, o tähte oleks vaja siia, siis oleks liblikas.

(11) Andreas 3;0.0

${ }^{*}$ CHI: ta tahtis, et tal oleks.

Kolmeaastaselt kasutab Andreas preesensis konditsionaali juba palju ja eri funktsioonides. Kolmeaastaselt tulevad ka esimesed pöördelõpuga konditsionaalivormid (siis autod näeksid, et ma näeksin). Andrease materjalis esineb 33 modaalverbivormi ja 50 et-konstruktsiooni (vt tabel 1) ning nende kasutusjuhud on üldiselt täiskasvanupärased. Ühe erandina võiks siin välja tuua näite (12), mis tõenäoliselt osutab konstruktsioonina omandamist ja viga sisuverbi lisamisel.

(12) Andreas 3;0.14

${ }^{*} \mathrm{CHI}$ : mis te tahaksite siit soovida?

Ema ja lapse konditsionaalivormid on omavahel kooskõlas: mida vanemaks saab laps, seda enam neid tuleb ema kõnesse. Esimesed materjalis registreeritud lapsele suunatud ema konditsionaalid esinevad söömisolukorras, kus ema küsib lapse tahtmiste kohta, näiteks aga mida sa tahaks süia? või soovitab midagi teha, nt aga käia pissil võiksid sa küll ära. 
Allpool tabelis 1 on esitatud preesensi konditsionaalivormide esinemissagedus Andreasel ja emal Andrease korpuses. Tabelist on näha, et Andreasel on kõige rohkem et-konstruktsioonis olevaid konditsionaalivorme, emal aga modaalverbide konditsionaale. See tulemus sobib hästi kokku Anneli Kauppineni (1998) tulemustega soome konditsionaali omandamisest: $e$-konstruktsioon näib ka eesti lapsel olevat väga tüüpiline konditsionaali esinemiskoht. ${ }^{11}$

Esimene konditsionaali perfektivorm esineb Andrease materjalis alles kolmeaastaselt, üldse on kogu materjalis ainult kolm lapse ja neli ema konditsionaali perfekti (13), (14). Lapse konditsionaalis on perfektid morfoloogiliselt korrektsed (oleks näinud ja oleks lusika peale pannud) ja esinevad et-konstruktsioonis (seega sama mudel kui preesensis), kuid ei ole kasutatud lauses täiskasvanupäraselt. Konditsionaali perfektivormid väljendavad eesti keeles tegelikult minevikku, preesensivormid aga tulevikku. On arvatud, et tulevik ongi lapsele selgem kui minevik, sest seostub tema soovide ja eesmärkidega (Tomasello 2005: 221). Kui minevik kombineerub aga konditsionaalse järeldamisega, nagu konditsionaali perfektivormides, peakski see lapsele olema kognitiivselt raskesti mõistetav.

(13) Andreas 3;0.13

${ }^{*} \mathrm{CHI}$ : mina ise tegin, ma tegin ise neid, et kasvatajatädi oleks näinud, misasjad ma olen teinud.

(14) Andreas 3;1.09

${ }^{*}$ CHI: olen näinud küll, et minu, et üks Pitsu oleks käpaga siit tardrikust [: taldrikust] lusika peale pannud ja poleks suhu pistnud.

Andrease materjali põhjal võime siis öelda, et ta on alustanud konditsionaalivormide omandamist sisu-, mitte modaalverbidest (värviks, kasvaks; oleks näinud, oleks pannud), kuid täiskasvanupärased kasutused tulevad siiski just modaalverbides ja et-konstruktsioonides. Vanuses 3;1 on Andreas preesensi konditsionaali kasutuse omandanud, sealhulgas kasutab ka pöördelõpuga vorme, kuid perfekti konditsionaal alles alustab oma teekonda tema keelde.

\section{Konditsionaalivormid lasteaialaste mängudes}

Vaatleme nüüd konditsionaalivorme Pirko Tõugu kogutud kolme lapse mänguvestlustes. Analüüsime 16 vestlust, igaühes räägivad vaba mängu ajal omavahel 3 last vanuses $3-5$. Selles mängukorpuses esines kokku 36 konditsionaalivormi, neist 34 olid preesensis, millest omakorda 25 olid modaalverbid; et-konstruktsioone oli 7 (vt tabel 1). Võrreldes Andrease korpuse lapse kõnega on seega modaalverbide osakaal tunduvalt suurem, see ületab ka modaalverbide suhtelist hulka Andrease ema konditsionaalivormide hulgas. Tabelis 1 ongi esitatud kõrvutavalt Andrease korpuse ja mänguvestluste korpuse preesensi konditsionaalivormide hulk.

11 Et-konstruktsioonid väljendavad tüüpiliselt lähitulevikus toimuva ennustust, mis on Bowermani (1986) andmetel ka inglise laste tingimuslausete esimesena ilmuv tähendus. 
Tabel 1. Preesensi konditsionaalivormid Andrease materjalis 2;0-3;1.11 ja mänguvestlustes

\begin{tabular}{|l|c|c|c|}
\hline \multirow{2}{*}{} & \multicolumn{2}{|c|}{ Andrease korpus } & \multirow{2}{*}{$\begin{array}{c}\text { Mänguvestluste } \\
\text { korpus }\end{array}$} \\
\cline { 2 - 3 } & Andreas & Ema & $24(70,5 \%)$ \\
\hline Modaalverbid & $33(33 \%)$ & $64(54 \%)$ & $7(20,5 \%)$ \\
\hline Et-konstruktsioon & $50(50 \%)$ & $22(19 \%)$ & $3(9 \%)$ \\
\hline Muud & $17(17 \%)$ & $32(27 \%)$ & $34(100 \%)$ \\
\hline Kokku & $100(100 \%)$ & $118(100 \%)$ & \\
\hline
\end{tabular}

Modaalverbidest sagedasim oli mänguvestlustes tahaks(in), mis esines kokku 15 korda. Selle materjali põhjal paistab, et tahaks väljendab lastel eelkõige lootusetut soovi (mitte viisakusest tingitud soovi pehmendamist). Näites (15) ütleb BAR alguses tahan õue minna, kuid mõistlik GER osutab konditsionaaliga (ja muidugi ka lausega aga ei saa), et see niikuinii ei ole võimalik. Hiljem on ka BAR juba konditsionaalne (st lootusetu) tahaks lõbusat ilma nüüd nautida. Selline kasutus on muidugi lähedane viisakuskonditsionaalile, kuid näib laste mänguolukordades (ja küllap ka täiskasvanutel) olevat ka päris omaette kasutusjuhtum, mida saadab ohkamine ja kurvastus.

(15) Tüdrukud omavahel: GER (4;0), BAR (4;2)

${ }^{*}$ GER: miks sa kogu aeg pead sama asja küsima.

*BAR: aga ma nii kangesti tahan õue minna!

*BAR: mulle meeldib õues olla.

*BAR: vot sellepärast, et ilma nautida.

*GER: jah, mina \#.

*GER: võibolla mina tahaksin ka õue minna aga ei saa.

*GER: näed ju.

*GER: peab toas olema.

*BAR: me ei saagi õue minna!

/.../

*BAR: mis küll võiks teha?

*GER: toas on nii igav eksju?

*BAR: jah!

*BAR: toas on igav.

*BAR: tahaks lõbusat \#.

*BAR: tahaks lõbusat ilma nüüd nautida!

*GER: ja kelgutada!

*BAR: jah!

Viisakuskonditsionaalideks võib tõlgendada laste omavahelistes mängudes esinevaid peaks/peaksid/peaksite vorme, millega väljendatakse eelkõige ettepanekuid mängukaaslastele. Näites (16) soovitab LEN mängukaaslastel veel rallikaid otsida.

(16) Kaks poissi (LEN, 4;9; JOP, 4;2) ja tüdruk (LAU, 4;4) omavahel mängimas

*LEN: otsime rallikaid.

*LEN: siin on üks rallikas. 
*LAU: see on ka rallika oma.

*LEN: sa peaksid veel siin \#.

${ }^{*}$ LEN: siin on veel üks selline ralline.

*LEN: rallikas.

*JOP: vaata, milline kabiin.

${ }^{*}$ LEN: peaksid otsima.

${ }^{*}$ LEN: otsi, otsi!

Materjalis on üks näide, milles verbivorm saaks esineb viisakuskonditsionaali funktsioonis, kuid seda on kasutatud täiskasvanuga suhtlemisel. Näites (17) on JOP tahtnud tulla mängima BRA autodega, kuid ta aetakse minema. JOP pöördub hädas eksperimentaatori poole, et see temaga mängiks. Lause kas sa saaksid sïn muga mängida? on selgelt palve ja konditsionaalil on siin intentsionaalne tõlgendus.

(17) Poisid omavahel: JOP (4;2), BRA (4;2), MAR (4;8)

*BRA: sina ei tule siia mängima.

*BRA: ma mängin.

*BRA: ma tahan üksi mängida!

*MAR: ta tahab üksi ka vahel mängida!

*BRA: mängitakse üksi.

*BRA: on ju üksi võib ka mängida!

*JOP: (täiskasvanule) kas sa saaksid siin muga mängida?

Mängukorpuses leidub tegelikult kõigi preesenskonditsionaali tähendusrühmade esindajaid. On ka et- ja muidu... konstruktsioone (vastavalt näiteks tahad, et ta hammustaks mul kätt ära? ja muidu kutsu ei kuuleks meie häält sïn.). Sealjuures on et-lausete osakaal umbes sama mis Andrease ema materjalis (vt tabel 1).

Perfektivormidest esineb materjalis aga ainult peaaegu-tähendus (avertiiv), nagu näites (18).

(18) Tüdrukud omavahel: AVE $(5 ; 1)$ ELI (4;9)

*AVE: pean tasakesi siit minema.

\%act: poeb lina alt läbi.

*ELI: hakkan minema.

*AVE: Laura oleks \#.

*AVE: Laurale oleks praegu see peale kukkund.

Materjalis ei esine kahetsev-parastavat kui oleks...siis oleks ega ka muid perfekti kasutuskontekste. Kas neid ka tegelikult selles vanuses lastel veel ei ole (kuna nad lihtsalt ei vaja selliseid väljendeid) või on tegemist materjali piiratusega, ei saa praegu veel öelda.

Mängukorpuse materjali põhjal võib veel kord kinnitada, et preesensi konditsionaal on selles vanuses juba hästi omandatud ja esineb eriti sageli ka täiskasvanute argikõne tavalisimas kontekstis - modaalverbides. Suhteliselt vähem (võrreldes nt Andrease ema kasutustega) on aga sisuverbide konditsionaale. 


\section{Kokkuvõte}

Artikkel käsitleb konditsionaalivorme kahes küllaltki erinevas korpuses: Andrease vestlustes oma vanematega vanuses $1 ; 7-3 ; 1$ ja $3-5$-aastaste laste omavahelistes mängudes. Siinses artiklis kasutatud materjali põhjal võib oletada, et konditsionaali omandamine algab nn sisuverbidest (nagu värviks, kasvaks, Andreasel umbes 2 aasta vanuses) ja konditsionaali tunnust lisab laps tüvedele juba varakult ka produktiivselt, millest annavad tunnistust mittetäiskasvanupärased vormid (on vajaks). Esimesed kasutused näivad olevat põhiliselt loovad, laps proovib lisada konditsionaali tunnust verbidele tõenäoliselt siis, kui tahab väljendada midagi, mida ta lähitulevikus sooviks. Kuna näited ei ole päris selgelt interpreteeritavad, peab lisama ka ettevaatlikuma tõlgenduse: kui laps ka ei soovi, siis väljendab ta nende verbidega olukordi, mida parajasti veel ei ole ja mis võiks ehk tulevikus tulla ning millesse võiks positiivselt suhtuda. Näib siiski, et esimesed konditsionaalivormid esindavad just konditsionaalset järeldamist, s.t mittereaalse olukorra esitamist.

Hilisemad konditsionaalivormid (alates vanusest 2;6) näitavad eelkõige konstruktsioonipõhist kasutust: enamik Andrease konditsionaalivormidest esineb etlausetes, palju ka modaalverbikonstruktsioonides. Morfoloogilisi vigu sel perioodil enam ei ole, Andreas ei ole moodustanud ühtegi mittetäiskasvanupärast vormi, kuid esineb veel pragmaatiliselt ebaõnnestunud lauseid. Nagu näitavad mõlemad kasutatud korpused, on kolme-nelja aasta vanune eesti laps konditsionaali preesensivormid tõenäoliselt hästi omandanud ja kasutab neid erinevates kontekstides. Lisaks lõputa konditsionaalidele tulevad umbes 3 aasta vanuses ka lõpuga vormid (siis autod näeksid, et ma näeksin). Mänguvestluste materjalis on konditsionaalivormis kõige sagedamini modaalverbid nagu täiskasvanutegi argikõnes.

Perfektivormide omandamine algab Andreasel 3 aasta vanuses, kuid kasutus ei ole esialgu täiskasvanupärane. Mänguvestluste korpuses, kus laste vanus on 3-5 aastat, on perfektivorme endiselt vähe, kuid nende kasutus on juba täiskasvanupärane. Näited jäävad siiski eelkõige ühte tüüpi: peaaegu oleks juhtunud (aga õnneks siiski mitte).

Seega toetavad siinse uurimise aluseks olnud Andrease konditsionaali omandamise andmed Anneli Kauppineni tulemusi ühe soome lapse vastava arengu kohta selles osas, et konditsionaalivormide omandamine toimub suuresti konstruktsioonide kaudu ja vastavalt lapse suhtlusvajadustele. Sisendkeel on oluline, kuid mitte ainumäärav, sest Andrease ema kõnes on modaalverbide ja et-konstruktsioonide osakaal lapse vastavatest vormidest erinev: emal on suhteliselt rohkem modaalverbe ja lapsel suhteliselt rohkem et-konstruktsioone. Laps ilmselt vajab oma suhtluseks pigem konditsionaalseid et-lauseid ja konditsionaalivormis modaalverbide kasutus on seetõttu harvem. Konditsionaalne järeldamine "peitub" omandamise käigus konstruktsioonidesse: korrektse kasutuse puhul ei ole enam võimalik üheselt ütelda, kas laps on omandanud grammatilise konstruktsiooni koos kogu tähendusega, mis sellel täiskasvanukeeles on, või konstrueerib terviku osadest ise, s.t kas ta konstrueerib tingliku mentaalse ruumi ja paigutab sellesse mingi sündmuse või on ta lihtsalt harjunud, et kui juhtus midagi ehmatavat (näiteks midagi kukkus), aga seekord siiski läks kõik hästi (ei kukkunud Laura peale), siis öeldakse selle kohta Laurale oleks peale kukkunud. Võib arvata, et täiesti täiskasvanupärane kasutus 
ja interpreteerimine arenevad välja hilisemas eas ja selle uurimine nõuab materjali siinsega võrreldes vanemas eas lastelt.

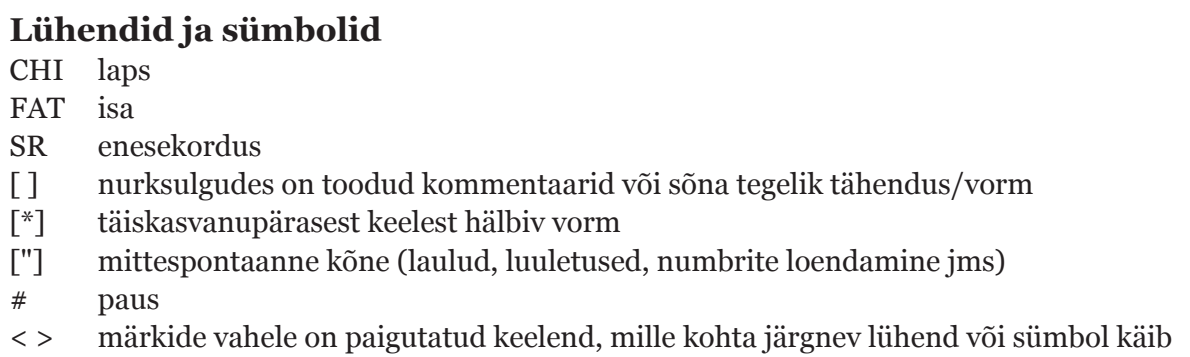

\section{Viidatud kirjandus}

Argus, Reili 2004. Eesti keele käändesüsteemi omandamine: esimestest sõnadest miniparadigmadeni. - Emakeele Seltsi aastaraamat, 50, 23-48.

Argus, Reili 2006. Eesti keele verbi ajamorfoloogia ja aspektilisuse omandamisest. - Emakeele Seltsi aastaraamat, 52, 1-20.

Bascelli, Elisabetta; Barbieri, Maria Silvia 2002. Italian children's understanding of the epistemic and deontic modal verbs dovere (must) and potere (may). - Journal of Child Language, 29, 1, 87-107. doi:10.1017/S0305000901004925

Blum-Kulka, Shoshana; Snow, Catherine E. 2004. The potential of peer talk. - Discourse Studies, 6, 3, 291-306. doi:10.1177/1461445604044290

Bowerman, Melissa 1986. First steps in aquiring conditionals. - Elizabeth Closs Traugott, Alice ter Meulen, Judy Snitzer Reilly, Charles A. Ferguson (Eds.). On Conditionals. Cambridge: Cambridge University Press.

Clark, Eve V.; Barbara F. Kelly 2006. Constructions and acquisition. - Eve V. Clark, Barbara F. Kelly (Eds.). Constructions in Acquisition. Stanford: CSLI Publications, 1-10.

Dancygier, Barbara; Eve Sweetser 2005. Mental Spaces in Grammar. Cambridge Studies in Linguistics. Cambridge: Cambridge University Press. doi:10.1017/ CBO9780511486760

Dressler, Wolfgang U.; Kilani-Schoch, Marianne; Klampfer, Sabine 2002. How does a child detect morphology? Evidence from production. - R. H. Baayen, R. Schreuder (Eds.). Morphological Structure in Language Processing. Trends in Linguistics. Studies and Monographs, 151. Berlin: Mouton Gruyter, 391-425.

EKG II = Erelt, Mati; Kasik, Reet; Metslang, Helle; Rajandi, Henno; Ross, Kristiina; Saari, Henn; Tael, Kaja; Vare, Silvi 1993. Eesti keele grammatika II. Süntaks. Lisa: kiri. Eesti Teaduste Akadeemia Keele ja Kirjanduse Instituut. Tallinn.

Elrod, Mimi Milner 1987. Children's understanding of indirect requests. - Journal of Genetic Psychology, 148, 1, 63-70. doi:10.1080/00221325.1987.9914537

Erelt, Mati; Metslang, Helle 2009. Some notes on proximative and avertive in Estonian. Linguistica Uralica, XLVII, 3, 178-191. doi:10.3176/lu.2009.3.02

Kauppinen, Anneli 1998. Puhekuviot, tilanteen ja rakenteen liitto: tutkimus kielen omaksumisesta ja suomen konditionaalista. Suomalaisen Kirjallisuuden Seuran toimituksia, 713. Helsinki: Suomalaisen Kirjallisuuden Seura.

Metslang, Helle 1999. Is the Estonian and Finnish conditional actually a conditional? - Mati Erelt (Ed.). Estonian: Typological Studies III. Publications of the Department of Estonian of the University of Tartu, 11. Tartu: Tartu Ülikool, 97-127. 
Pajusalu, Renate; Tragel, Ilona; Veismann, Ann; Vija, Maigi 2004. Tuumsõnade semantikat ja pragmaatikat. Tartu: Tartu Ülikooli Kirjastus.

Pajusalu, Renate; Pajusalu, Karl 2004. The conditional in everyday Estonian: its form and functions. - Linguistica Uralica, XL, 4, 257-269.

Pajusalu, Renate; Pajusalu, Karl 2010. Konditsionaal relatiivlauses. - Eesti ja soome-ugri keeleteaduse ajakiri, 2, 243-254.

Pajusalu, Renate (ilmumas). Referential properties of concealed subjects in Estonian.- MarjaLiisa Helasvuo, Tuomas Huumo (Toim.). Cognitive and Interactional Perspectives on Non-Canonical Subjects.

Piaget, Jean 1932. The Moral Judgement of the Child. London: Routledge.

Reilly, Judy Snitzer 1986. The aquisition of temporals and conditionals. - Elizabeth Closs Traugott, Alice ter Meulen, Judy Snitzer Reilly, Charles A. Ferguson (Eds.). On Conditionals. Cambridge: Cambridge University Press.

Shatz, Merilin 1978. Children's comprehension of their mothers' question directives. - Journal of Child Language, 5, 1, 39-46. doi:10.1017/So305000900001926

Tomasello, Michael 2005. Constructing a Language: A Usage-based Theory of Language Acquisition. London: Harvard University Press.

Stolt, Suvi; Haataja, Leena; Lapinleimu, Helena; Lehtonen, Liisa 2009. Associations between lexicon and grammar at the end of the second year in Finnish children. - Journal of Child Language, 36, 4, 779-806. doi:10.1017/S0305000908009161

Torn-Leesik Reeli; Maigi Vija (ilmumas). The acquisition of the impersonal voice by an Estonian child. - Journal of Baltic Studies.

Tragel, Ilona 2003. Eesti keele tuumverbid. Dissertationes linguisticae Universitatis Tartuensis, 3 Tartu: Tartu Ülikooli Kirjastus.

Tõugu, Pirko; Tulviste, Tiia 2010. References to social norms by preschool children and their linguistic expression. - European Journal of Developmental Psychology, 7, 2, 249-264. doi:10.1080/17405620802194092

\section{Võrgumaterjalid}

Andmebaasi CHILDES eesti keele korpus. http://childes.psy.cmu.edu/data/Other/Estonian/ (20.02.2011).

Tartu Ülikooli suulise kõne korpus. http://www.cl.ut.ee/suuline/ (20.02.2011).

Renate Pajusalu (Tartu Ülikool) on uurinud eesti keele semantikat ja pragmaatikat, muuhulgas ka kognitiivse keeleteaduse vaatenurgast; on tegelenud esimese ja teise keele omandamisega, viimasel ajal grammatika ja sõnavara arenguga 3-7-aastastel lastel.

renate.pajusalu@ut.ee

Pirko Tõugu (Tartu Ülikool) on arengupsühholoogina uurinud laste sotsialiseerumist. pirko@ut.ee

Maigi Vija (Tartu Ülikool) on uurinud esimese keele omandamist, sh morfoloogiat ja pronoomenikasutust.

maigi.vija@ut.ee

Tiia Tulviste (Tartu Ülikool) on arengupsühholoogina teinud mitmeid uurimusi laste kõne arengust, uurinud emade suhtlemist oma lastega Eestis, Lätis, Rootsis, USA-s ja Soomes; praegu uurib laste sotsialisatsiooni Läänemere-äärsetes maades: Eestis, Saksamaal ja Rootsis.

Tiia.Tulviste@ut.ee 


\title{
THE ACQUISITION OF THE ESTONIAN CONDITIONAL IN CHILD LANGUAGE
}

\author{
Renate Pajusalu, Pirko Tõugu, \\ Maigi Vija, Tiia Tulviste \\ University of Tartu
}

This article examines the acquisition of the Estonian conditional in child language. The data comes from two small corpora: the CHILDES corpus of Andreas (age $1 ; 7-3 ; 1)$ and his parents and the corpus of children's (age $3-5$ ) conversations during play in groups of three. The Estonian conditional marker is $-k s(i)$, which is added to the stem of the verb, e.g. ole $+k s$ '(it) would be'. In the 1st and 2nd person singular and in all persons in the plural it may be followed by a morpheme indicating the person, e.g. ole $+k s i+n$ 'I would be'. It is common to leave the person-ending out, e.g. oleks 'I/you/he etc. would be'. The conditional has two tense forms: the present conditional (used mostly to express the future), and the perfect conditional (expresses the past). The first conditionals occur in Andreas' corpus at the age of 2;0; the adult-like usage of the present conditional without person-marking can be observed at the age of 2;6. The person-marked conditional forms occur at the age of 3 ; 0 . The perfect conditional occurs at the age of $3 ; 0$ as well, but it is not yet used in an adult-like way. In the playtime conversation corpus the present perfect occurs at the age of 4 and 5 and it is used in an adult-like way, but only in some restricted constructions (e.g. oleks kukkunud 'would have fallen'). In child language the co-influence of constructional acquisition via input and the conversational needs of the child can be observed. In the speech of Andreas' mother, constructions of conditional modal verbs prevail (peaks sööma 'should eat'), while in the child's language the most frequent constructions are those beginning with $e t$ 'that' (e.g. et läheks mina puhtaks 'to make me clean').

Keywords: first language acquisition, verb morphology, the conditional mood, constructions, Estonian 